\title{
Colloid, Blood, and Kidney: Chemistry Topics to Support Meaningful Learning for Biology Students
}

\author{
Syarifa Wahida Al-Idrus, Aliefman Hakim, Supriadi, Suriya Ningsyih \\ Study Program of Chemical Education, FKIP University of Mataram, Mataram, Indonesia \\ Email: aliefmanhakim27@gmail.com
}

How to cite this paper: Al-Idrus, S. W., Hakim, A., Supriadi, \& Ningsyih, S. (2019). Colloid, Blood, and Kidney: Chemistry Topics to Support Meaningful Learning for Biology Students. Creative Education, 10, 650-654.

https://doi.org/10.4236/ce.2019.104047

Received: October 19, 2018

Accepted: April 1, 2019

Published: April 4, 2019

Copyright $\odot 2019$ by author(s) and Scientific Research Publishing Inc. This work is licensed under the Creative Commons Attribution International License (CC BY 4.0).

http://creativecommons.org/licenses/by/4.0/

\begin{abstract}
Biology students desperately need chemistry because chemistry explains in detail why a biological process occurs. However, there are still many biology students who consider chemistry a difficult subject to study. This topic supports meaningful learning for biology students. Biology topics that are closely related to colloid topics are the nature of blood as colloids, the ability of the kidneys to cleanse the blood, and the working principle of a dialysator that can replace the kidneys in cleansing the blood.
\end{abstract}

\section{Keywords}

Colloid, Blood, Kidney, Chemistry, Meaningful Learning

\section{Introduction}

Biology students desperately need chemistry because chemistry explains in detail why a biological process occurs. However, there are still many biology students who consider chemistry a difficult subject to study. Students do not know the role of chemistry in biology. Their ignorance is caused by the lack of meaningful chemistry learning. One of them is because the chemical topics studied in the class are not related to biology. Chemistry learning that is associated with biology is a meaningful learning for biology students.

Meaningful learning occurs when students build the knowledge and cognitive processes needed for successful problem solving (Hakim et al., 2016). Meaningful learning is recognized as an important educational goal (Hakim \& Jufri, 2018). It requires that instruction goes beyond simple presentation of Factual Knowledge and that assessment tasks require more of students than simply re- 
calling or recognizing Factual Knowledge. The cognitive processes summarized here describe the range of students' cognitive activities in meaningful learning; that is, these processes are ways students can actively engage in the process of constructing meaning (Mayer, 2002).

The most important single factor influencing learning is what the learner already knows. Therefore meaningful learning, which implies longer retention than memorizing, occurs when humans relate new concepts to pre-existing familiar concepts. Then changes are produced in our cognitive structure, concepts are modified and new links are created. It is a useful tool because it enables real learning, it generates greater retention and it facilitates transferences to other real situations (Vallori, 2014).

Meaningful learning occurs when there is a willingness, readiness, and motivation to learn (Hakim \& Jufri, 2017). Meaningful learning will also occur if the topic studied is relevant to the students' environment (Hakim et al., 2018). In addition, teaching materials that are prepared must also be in accordance with the needs of students for learning to be effective and efficient. That way students can construct and apply the knowledge they have acquired (Valadares, 2013).

Meaningful chemical learning can also motivate biology students to always study chemistry. According to Westbroek (2005) learning that is appropriate for students' lives will motivate them to learn. According to Fan et al. (2013) meaningful learning can improve learning outcomes and motivation.

One of the important chemical topics to be mastered by biology students is the topic of colloid. The concept of colloid is a topic that is closely related to biology. But in teaching, Colloid topic tends to be memorized by students. Novilia (2016) stated that in the Colloid topic, students are usually required to memorize its content, even though students can get any kind of learning sources. The memorizing method causes several misconceptions. There are several misconceptions in Colloid topic, such as: Students assume that solution is a mixture which is composed of kinds of substances and water; solution is always thin; and colloid is always thick.

Based on observations, the topic of colloid given in class is not integrated with biology. The topic of colloid given only explains the concept of colloid, colloidal properties, various colloids, and how to make colloids without giving examples related to biology. This can make biology students less motivated in studying colloids so they don't understand colloids. In fact, colloids are related to biological science. According to Young (2016) Colloidal systems are essential to life. They are extremely useful, even indispensable, in many commercial and industrial situations as well. They function in everybody cell, in the blood, and in all body fluids, especially the intercellular fluids, formerly known as "humours." Therefore, increased understanding of colloids and their attendant phenomena, as well as the application of their operating principles, to enhance human health.

Therefore, it is necessary to develop colloidal teaching materials related to biology to support meaningful learning for biology students. This research is use- 
ful to motivate biology students to always study chemistry.

\section{Research Method}

This research is a development research that develops chemistry teaching materials for biology students. The chemistry material provided is very related to biology. This development research was carried out through a combination of literature study and field study. Literature study was done by looking for biological topics that are relevant to colloid topic. Field study was conducted by observing the basic chemistry courses of biology students conducted by lecturer at one of the state universities in Mataram city. Field studies are also conducted by reviewing the teaching materials used in basic chemistry courses. Field study was conducted with the aim to evaluate whether the learning process and the teaching materials used are meaningful.

\section{Discussion}

Colloid is one of the topics taught to biology students. The topic of colloids taught consists of the understanding of colloid systems, types of colloids, colloidal properties, and methods of making colloids. Colloid learning needs to be linked to biology so that meaningful learning occurs.

Biology topics related to colloid are the nature of blood, which are colloid, the process of wound closure, the process of dialysis by the kidneys, and the dialysis machine. All colloid topics can be explained using the nature of blood as an example. The function of blood in the body can be explained based on colloidal properties.

Blood is a type of colloid with dispersing phase in the form of liquid and dispersed phase in the form of solids. Why is blood in the form of colloids? Colloids in the blood are formed because blood cells are dispersed solids in plasma proteins in the form of liquid. Colloids affect the level of blood viscosity. In other words, blood is a type of colloid called sol which is a dispersed solid in liquid.

There are many benefits of blood, which include transporting oxygen from the lungs to tissues and $\mathrm{CO}_{2}$ from the tissues to the lungs, to transport absorbed food substances, to transport metabolic waste to the kidneys, lungs, skin and intestines to discarded, and maintain acid-base balance in the body. Blood transport function can occur due to colloidal blood. All substances, both gas, liquid and solid can be transported by blood because they are colloidal. One of the colloidal properties that is capable of transporting substances is adsorption. The nature of blood that is capable of transporting various substances in the body can be used in explaining the topic of colloids such as colloidal properties, one type of colloid (sol type), and colloidal benefits that can be directly felt in the body.

Another benefit of blood is to carry metabolic waste substances and foreign substances to the kidneys. In the kidney, all residual substances and foreign substances will be taken by the kidneys. This process is also a colloidal property 
called dialysis. Dialysis is the process of removing colloidal charge through a diffusion process through the semipermeable membrane. This membrane has pores that are able to penetrate by ions, but cannot be penetrated by colloidal particles. When blood passes through the kidney, all the ions in the blood will diffuse through a semipermeable membrane in the kidney. When the kidneys filter blood, urine will be created from waste substances and excess fluid in the body. The urine is then drained through the ureter to then be carried to the bladder and removed as urine. This process can be used to explain one of the benefits of colloidal properties, namely the dialysis process.

If the kidneys do not work normally, then the residual substances in the blood will accumulate and cause reduced blood function so that the need for a device can function like a kidney. The device is called a kidney function replacement dialysator for kidney failure patients. The use of kidney properties and colloidal properties can be used to explain the benefits of colloids in the body.

All topics related to blood and kidneys can be used to improve students' understanding of colloid. It is because learning that links colloid topic with blood and kidneys can provide meaningful learning for students. The development of the topic is expected to be applied in schools to provide meaningful chemistry learning.

\section{Conflicts of Interest}

The authors declare no conflicts of interest regarding the publication of this paper.

\section{References}

Fan, K. K., Su, C. H., Deng, S. Y., \& Wang, W. J. (2013). An Achievement Prediction Model of Meaningful Learning, Motivation, and Cognitive on SPANI: Partial Least Square Analysis. Mathematical Problems in Engineering, 2013, Article ID: 961963. https://doi.org/10.1155/2013/961963

Hakim, A., \& Jufri, A. W. (2017). Applications of Isolation and Structure Elucidation of Secondary Metabolites in Natural Product Chemistry Laboratory. In Advances in Chemistry Research (Book Chapter). New York: NOVA Publisher.

Hakim, A., \& Jufri, A. W. (2018). Natural Products Laboratory Project: Isolation and Structure Elucidation of Piperin from Piper nigrum and Andrographolide from Andrographis paniculata. Journal of Turkish Science Education, 15, 15-28.

Hakim, A., Andayani, Y., \& Rahayuan, B. D. (2018). Isolation of Ethyl P-Methoxy Cinnamate from Kaemferia galanga L. Journal of Physics: Conf. Series, 1095, 012039. https://doi.org/10.1088/1742-6596/1095/1/012039

Hakim, A., Liliasari, Kadarohman, A., \& Syah, Y. M. (2016). Improvement of Student Critical Thinking Skills with the Natural Product Mini Project Laboratory Learning. Indonesian Journal of Chemistry, 16, 315-321.

Mayer, R. E. (2002). Rote versus Meaningful Learning. Theory into Practice, 41, 226-232. https://doi.org/10.1207/s15430421tip4104_4

Novilia, L., Iskandar, S. M., \& Fauziatul, F. (2016). The Effectiveness of Colloid Module Based on Guided Inquiry Approach to Increase Students' Cognitive Learning Outcomes. 
International Journal of Education, 9, 17-23. https://doi.org/10.17509/ije.v9i1.3713

Valadares, J. (2013). Concept Maps and the Meaningful Learning of Science. Journal for Educators, Teachers and Trainers, 4, 164-179.

Vallori, A. B. (2014). Meaningful Learning in Practice. Journal of Education and Human Development, 3, 199-209. https://doi.org/10.15640/jehd.v3n4a18

Westbroek, H. B. (2005). Characteristics of Meaningful Chemistry Education: The Case of Water Quality. Utrecht: CD- $\beta$ Press.

Young, R. O. (2016). Colloids and Colloidal Systems in Human Health and Nutrition. International Journal of Complementary \& Alternative Medicine, 3, Article ID: 00095. 